\title{
An Empirical Study of the Quality Evaluation in Logistic Service of the B2C E-commerce Companies in China
}

\author{
Ning Lei \\ $X i$ 'an International University \\ leining.82@163.com
}

\begin{abstract}
As the outsourcing of key suppliers and business processes becomes increasingly popular, the evaluation and selection of the logistics outsourcing companies is of critical importance in supply chain management. However, there are few quantitative studies on the investigation of the main affecting factors of the logistics service quality focused on the market in China, which is one of the developing countries with the highest online population growth. This paper is an attempt to identify the main factors affecting the logistics service satisfaction of the B2C e-commerce sites in China, and Fisher's exact test is applied to identify the main affecting factors of logistics service satisfaction and evaluation. The results could be the guideline for the e-commerce companies in terms of improving their outsourcing logistics services.
\end{abstract}

Keywords: logistics service, Fisher's exact test, empirical study, China

\section{Introduction}

The past few years have witnessed a dramatic shift in the manner of conducting business. National economics have become more and more interdependent, incurring tremendous pressure on companies to maximize productivity and profitability [1]. Many companies start to shift from integrated supply chains to strategic partnerships with external entities, and resulted in a dramatic change of supply chain management. As is known to all that creating value through outsourcing has emerged as a popular competitive strategy for many companies.

With the growing level of complexity tied to outsourcing, many companies have resorted to outsourcing their logistics service in their supply chain management. A good logistics service provider can improve the customer satisfaction and reduce the cost of the core company in supply chain. It is necessary for the companies to identify customers' needs, wants, and preferences in order to deliver high quality service performance [2]. However, there are few quantitative studies on the investigation of the main affecting factors of the logistics service quality of the e-commerce companies in China.

This paper is an attempt to identify the main factors affecting outsourcing logistics service quality for the e-commerce companies in China, which could be the guideline for the selecting the best logistics service suppliers for the companies. The remainder of this study is organized as follows. Section 2 introduces the related literature about the logistics service quality. Following is a brief introduction about the Fisher's exact test which is employed in this research. Section 4 discusses the main factors that may have an impact on the logistics service in China. In the last section, the related managerial implications of this research are discussed. 


\section{Literature Review}

Logistics services in the outsourcing market were confined to the traditional activities such as transportation and warehousing in the early 1980s. In the 1990s, a number of network players began to provide a wider geographic coverage of their transport networks, and many value adding activities such as labeling and sorting were introduced. In the late 1990s, a number of players from areas as information technology, management consultancy and financial services began working together with logistics service providers [3-5].

A series of researches about logistics service evaluation are studied in the related researches. Table 1 summarizes the related research results:

Table 1. Logistics Service Evaluation in Prior Related Research

\begin{tabular}{ll}
\hline Article & Logistics service evaluation criteria \\
\hline Yahya and Kingsman & $\begin{array}{l}\text { Quality, response delivery and performance of financial } \\
\text { management technical ability and facilities } \\
\text { Guo (1999)[7] }\end{array}$ \\
$\begin{array}{l}\text { Quality, price, technical ability and distribution reliability } \\
\text { Quality, price, delivery, service, product development and } \\
\text { production, external environment, and other (sales and marketing } \\
\text { staff in general) } \\
\text { Product quality, the price, the post-sale service, the technical } \\
\text { level, the geographical position, supply capacity, economic } \\
\text { benefit, delivery and market effect }\end{array}$ \\
Ma (2002)[9] & $\begin{array}{l}\text { Technical level, management ability, and service level and } \\
\text { management environment }\end{array}$ \\
Zhong et al. (2003)[10] & $\begin{array}{l}\text { High homogeneity, the reliability and validity of the structures } \\
\text { Input-output efficiency, the equipment utilization efficiency, } \\
\text { quality assurance, efficiency, market competition efficiency } \\
\text { Thou et al. (2005)[11] } \\
\text { Sun (2006)[12] }\end{array}$ \\
Hsiao et al. (2010)[13] & $\begin{array}{l}\text { logistics cost, the logistics operation efficiency, the basic qualities } \\
\text { of service suppliers and logistics technology }\end{array}$ \\
Peng (2012)[14] & $\begin{array}{l}\text { Cost, delivery, flexibility, quality, technology and risk } \\
\text { Cost, logistic ability, logistic time and extendibility }\end{array}$ \\
Ho et al. (2012)[15] &
\end{tabular}

\section{Methodology}

Fisher's exact test was first proposed in 1992[17]. It is a statistical significance test in the analysis of contingency tables, and is suitable for the analysis when some of the frequencies are low and use of the chi-squared test is ruled out (i.e. some expected values are 0 or less than twenty percents are less than 5). Fisher's exact test is one of a class of exact tests because the significance of the deviation from a null hypothesis can be calculated exactly, rather than relying on an approximation that becomes exact in the limit as the sample size grows to infinity, as with many statistical tests.

The following is an example to illustrate the theory of the fisher's exact test: a sample of teenagers might be divided into male and female on the one hand, and those that are and are not currently dieting on the other. The hypothesis is that the proportion of dieting individuals is higher among the women than the men, and whether any difference of proportions is significant is tested, and the data is shown as follows: 
Table 2. The $2^{\star} 2$ Contingency Table for the Sample

\begin{tabular}{|l|l|l|l|}
\hline & Men & Women & Row total \\
\hline Dieting & 1 & 9 & 10 \\
\hline Non-dieting & 11 & 3 & 14 \\
\hline Column total & 12 & 12 & 24 \\
\hline
\end{tabular}

These data would not be suitable for analysis by Pearson's chi-squared test, because the expected values in the table are all below 10 , and in a $2 * 2$ contingency table, the number of degrees of freedom is always 1 .

Before we proceed with the Fisher's exact test, we first introduce some notation. We represent the cells by the letters a, b, c and d, call the totals across rows and columns marginal totals, and represent the grand total by $\mathrm{n}$ :

\section{Table 3. The $2 * 2$ Contingency Table for the Sample with the Representative Letters}

\begin{tabular}{|l|l|l|l|}
\hline & Men & Women & Row total \\
\hline Dieting & $a$ & $b$ & $a+b$ \\
\hline Non-dieting & $c$ & $d$ & $c+d$ \\
\hline Column total & $a+c$ & $b+d$ & $a+b+c+d=n$ \\
\hline
\end{tabular}

The probability of obtaining any such set of values was given by the hypergeometric distribution:

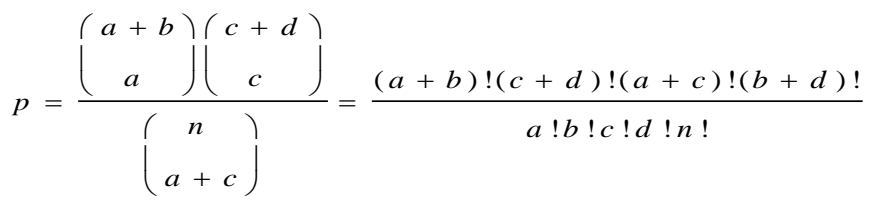

Where $\left(\begin{array}{l}n \\ k\end{array}\right)$ is the binomial coefficient and the symbol indicates the factorial operator.

$$
p=\frac{\left(\begin{array}{ll}
1 & 0 \\
1
\end{array}\right)\left(\begin{array}{l}
14 \\
1
\end{array}\right)}{\left(\begin{array}{l}
24 \\
1
\end{array}\right)}=\frac{10 ! 14 ! 12 ! 12 !}{1 ! 9 ! 11 ! 3 ! 24 !} \approx 0.001346076
$$

The formula above gives the exact hypergeometric probability of observing this particular arrangement of the data, assuming the given marginal totals, on the null hypothesis that men and women are equally likely to be dieters. To put it another way, if we assume that the probability that a man is a dieter is $\mathrm{p}$, the probability that a woman is a dieter is $p$, and it is assumed that both men and women enter our sample independently of whether or not they are dieters, then this hypergeometric formula gives the conditional probability of observing the values $\mathrm{a}, \mathrm{b}, \mathrm{c}, \mathrm{d}$ in the four cells, conditionally on the observed marginals. This remains true even if men enter our sample with different probabilities than women. The requirement is merely that the two classification characteristics: gender and dieter are not associated.

For example, suppose we knew probabilities $P, Q, p, q$ with $P+Q=p+q=1$ such that (male dieter, male non-dieter, female dieter, female non-dieter) had respective probabilities $(P p, P q, Q p, Q q)$ for each individual encountered under our sampling procedure. The next 
step is to calculate the exact probability of any arrangement of these teenagers into the four cells of the table, but Fisher's exact test showed that to generate a significance level, we need consider only the cases where the marginal totals are the same as in the observed table, and among those, only the cases where the arrangement is as extreme as the observed arrangement, or more so. In this example, there are 11 such cases. Of these only one is more extreme in the same direction as our data:

\section{Table 4. The $2 * 2$ Contingency Table for the Sample Considering the Marginal Totals}

\begin{tabular}{|l|l|l|l|}
\hline & Men & Women & Row total \\
\hline Dieting & 0 & 10 & 10 \\
\hline Non-dieting & 12 & 2 & 14 \\
\hline Column total & 12 & 12 & 24 \\
\hline
\end{tabular}

So the probability is $p=\frac{\left(\begin{array}{l}10 \\ 0\end{array}\right)\left(\begin{array}{l}14 \\ 12\end{array}\right)}{\left(\begin{array}{l}24 \\ 12\end{array}\right)} \approx 0.000033652$

In order to calculate the significance of the observed data, i.e. the total probability of observing data as extreme or more extreme if the null hypothesis is true, we have to calculate the values of $p$ for both these tables, and add them together. This gives a one-tailed test, with $p$ approximately $0.001346076+0.000033652=0.001379728$. This value can be interpreted as the sum of evidence provided by the observed data for the null hypothesis (that there is no difference in the proportions of dieters between men and women). The smaller the value of $p$, the greater the evidence for rejecting the null hypothesis; so here the evidence is strong that men and women are not equally likely to be dieters.

For a two-tailed test we must also consider tables that are equally extreme, but in the opposite direction. An approach used by the Fisher' exact test is to compute the $p$-value by summing the probabilities for all tables with probabilities less than or equal to that of the observed table. In the example here, the 2-sided p-value is twice the 1-sided value-but in general these can differ substantially for tables with small counts, unlike the case with test statistics that have a symmetric sampling distribution.

\section{Data Collection and Results Analysis}

\subsection{Questionnaire Design}

The specific factors that may have high influence on the logistics service satisfaction are listed in Table 5. The questionnaire is designed based on these factors, and the respondents are required to evaluate the related situations based on Five-point scale method (1 indicates the worst evaluations, while 5 indicates the best evaluation). 


\section{Table 5. The Factors may have High Influence on the Logistics Service} Satisfaction

\begin{tabular}{ll}
\hline Goal & Criteria \\
\hline & $C_{1}$ Cost \\
& $C_{2}$ Delivery \\
& $C_{3}$ Flexibility \\
& $C_{4}$ Input-output efficiency \\
& $C_{5}$ Management ability \\
Assessment of logistics & $C_{6}$ Service \\
service quality & $C_{7}$ Management environment \\
& $C_{8}$ Quality assurance \\
& $C_{9}$ Technology \\
& $C_{10}$ Risk \\
& $C_{11}$ Logistics time \\
& $C_{12}$ Extendibility \\
& $C_{13}$ Validity of the structure \\
& $C_{14}$ Market effect \\
& $C_{15}$ Economic benefit \\
\hline
\end{tabular}

Considering the differences among $\mathrm{B} 2 \mathrm{C}, \mathrm{C} 2 \mathrm{C}$ and $\mathrm{B} 2 \mathrm{~B}$ e-commerce, and our research is focus on $\mathrm{B} 2 \mathrm{C}$ e-commerce websites in China, the top $10 \mathrm{~B} 2 \mathrm{C}$ e-commerce websites in retail market shown in table 6 are selected based on the user coverage.

\section{Table 6. Top 10 B2C e-commerce Websites in Retail Market in China}

\begin{tabular}{llc}
\hline No. & E-Commerce Website & No. of users (per million) \\
\hline 1 & Tmall & 9010 \\
2 & Jingdong Mall & 6940 \\
3 & Tencent & 3930 \\
4 & Amazon & 3450 \\
5 & Handle group buying & 2580 \\
6 & Dangdang & 2160 \\
7 & Vancl & 2160 \\
8 & Full King & 1290 \\
9 & No.1 & 1050 \\
10 & F group buying & 770 \\
\hline
\end{tabular}

The customers are required to identify 1-5 e-commerce websites logistics service providers that they are most familiar with and evaluate the logistics service. The selected managers of the logistics departments of the e-commerce companies are asked to evaluate the related aspects of their logistics service suppliers.

\subsection{Internal Consistency Test}

In statistics and research, internal consistency is typically a measure based on the correlations between different items on the same test (or the same subscale on a larger test). It measures whether several items that propose to measure the same general construct produce similar scores. Cronbach's $\alpha$ is used to measure the internal consistency of the data in this research. It was first named alpha by Lee Cronbach in 1951, and it is widely used in the social sciences, business, nursing and other disciplines. 
Cronbach's $\alpha$ is defined as:

$$
\alpha=\frac{K}{K-1}\left(1-\frac{\sum S_{\mathrm{i}}^{2}}{S_{T}^{2}}\right)
$$

Where $K$ is the number of the components ( $K$-items), $S_{T}^{2}$ is the variance of the observed total test scores, and $S_{i}^{2}$ is the variance of component $i$ for the current samples.

The Cronbach's $\alpha$ is 0.6378 in this research which means that the internal consistency is acceptable.

\subsection{Fisher's Exact Test}

The hypotheses and the Fisher's exact test process related with logistics service evaluation factors are as follows:

Hypothesis-1(a): Cost $\left(\mathrm{C}_{1}\right)$ has a significant influence on logistics service satisfaction

Hypothesis-1(b): Cost $\left(\mathrm{C}_{1}\right)$ has a lower influence on logistics service satisfaction

Table 7. Logistics Service Satisfaction* C1 Impact Analysis Chi-Square Tests

\begin{tabular}{|l|r|r|r|r|r|r|}
\hline & Value & df & $\begin{array}{c}\text { Asymp. Sig. (2- } \\
\text { sided) }\end{array}$ & $\begin{array}{c}\text { Exact Sig. } \\
\text { (2-sided) }\end{array}$ & $\begin{array}{c}\text { Exact Sig. } \\
\text { (1-sided) }\end{array}$ & $\begin{array}{c}\text { Point } \\
\text { Probability }\end{array}$ \\
\hline Pearson Chi-Square & $42.780 \mathrm{a}$ & 16 & .000 & .000 & & \\
Likelihood Ratio & 34.308 & 16 & .005 & .002 & & \\
Fisher's Exact Test & 27.260 & & & .002 & & \\
Linear-by-Linear Association & $7.869 \mathrm{~b}$ & 1 & .004 & .002 & .001 \\
N of Valid Cases & 33 & & & & & \\
\hline
\end{tabular}

a. 25 cells $(100.0 \%)$ have expected count less than 5 . The minimum expected count is .06 .

b. The standardized statistic is 2.805 .

As shown in Table 7,the value of Fisher's Exact Test is 27.260,Exact Sig.(2-sided) is 0.002 , which is lower than 0.05 , therefore Hypothesis-1(a)is accepted with significant level of $5 \%$, which means that cost has a significant influence on logistics service satisfaction.

Hypothesis-2(a): Delivery $\left(\mathrm{C}_{2}\right)$ has a significant influence on logistics service satisfaction

Hypothesis-2(b): Delivery $\left(\mathrm{C}_{2}\right)$ has a lower influence on logistics service satisfaction

Table 8. Logistics Service Satisfaction* C2 Impact Analysis

Chi-Square Tests

\begin{tabular}{|l|l|l|l|l|l|l|}
\hline & Value & df & $\begin{array}{l}\text { Asymp. Sig. (2- } \\
\text { sided) }\end{array}$ & $\begin{array}{l}\text { Exact Sig. } \\
\text { (2-sided) }\end{array}$ & $\begin{array}{l}\text { Exact Sig. } \\
\text { (1-sided) }\end{array}$ & $\begin{array}{l}\text { Point } \\
\text { Probability }\end{array}$ \\
\hline Pearson Chi-Square & $36.206 \mathrm{a}$ & 12 & .000 & .000 & & \\
Likelihood Ratio & 33.149 & 12 & .001 & .000 & \\
Fisher's Exact Test & 25.173 & & & .000 & \\
Linear-by-Linear Association & $15.898 \mathrm{~b}$ & 1 & .000 & .000 & .000 & .000 \\
N of Valid Cases & 33 & & & & & \\
\hline
\end{tabular}

a. 18 cells $(90.0 \%)$ have expected count less than 5 . The minimum expected count is .09.

b. The standardized statistic is 3.987 . 
As shown in Table 8,the value of Fisher's Exact Test is 25.173,Exact Sig.(2-sided) is 0.000 ,lower than 0.05 ,therefore Hypothesis-2(a)is accepted with significant level of 5\%, which means that delivery $(\mathrm{C} 2)$ has a significant influence on logistics service satisfaction.

Hypothesis-3(a): Flexibility $\left(\mathrm{C}_{3}\right)$ has a significant influence on logistics service satisfaction

Hypothesis-3(b): Flexibility $\left(\mathrm{C}_{3}\right)$ has a lower influence on logistics service satisfaction

Table 9. Logistics Service Satisfaction * C3 Impact Analysis

\begin{tabular}{|c|c|c|c|c|c|c|}
\hline \multicolumn{7}{|c|}{ Chi-Square Tests } \\
\hline & Value & df & $\begin{array}{c}\text { Asymp. Sig. } \\
\text { (2-sided) }\end{array}$ & $\begin{array}{l}\text { Exact Sig. } \\
\text { (2-sided) }\end{array}$ & $\begin{array}{l}\text { Exact Sig. } \\
\text { (1-sided) }\end{array}$ & $\begin{array}{c}\text { Point } \\
\text { Probability }\end{array}$ \\
\hline Pearson Chi-Square & $20.807 \mathrm{a}$ & 16 & .186 & .209 & & \\
\hline Likelihood Ratio & 25.463 & 16 & .062 & .054 & & \\
\hline Fisher's Exact Test & 20.191 & & & .082 & & \\
\hline Linear-by-Linear Association & $.045 b$ & 1 & .832 & .845 & .435 & .038 \\
\hline $\mathrm{N}$ of Valid Cases & 33 & & & & & \\
\hline
\end{tabular}

a. 23 cells $(92.0 \%)$ have expected count less than 5 . The minimum expected count is .09.

b. The standardized statistic is -.213 .

As shown in Table 9, the value of Fisher's Exact Test is 20.191,Exact Sig.(2-sided) is 0.082 ,lower than 0.05 ,therefore hypothesis-3(a)is rejected.

Hypothesis-4(a): Input-output efficiency $\left(\mathrm{C}_{4}\right)$ has a significant influence on logistics service satisfaction

Hypothesis-4(b): Input-output efficiency $\left(\mathrm{C}_{4}\right)$ has a lower influence on logistics service satisfaction

Table 10. Logistics Service Satisfaction * C4 Impact Analysis

Chi-Square Tests

\begin{tabular}{|l|r|r|r|r|r|r|}
\hline & \multicolumn{1}{|c|}{ Value } & df & $\begin{array}{c}\text { Asymp. Sig. } \\
\text { (2-sided) }\end{array}$ & $\begin{array}{c}\text { Exact Sig. } \\
\text { (2-sided) }\end{array}$ & $\begin{array}{c}\text { Exact Sig. } \\
\text { (1-sided) }\end{array}$ & $\begin{array}{c}\text { Point } \\
\text { Probability }\end{array}$ \\
\hline Pearson Chi-Square & $\begin{array}{r}\text { (10.223a } \\
\text { Likelihood Ratio }\end{array}$ & 16 & .001 & .002 & & \\
Fisher's Exact Test & 39.901 & 16 & .001 & .000 & & \\
Linear-by-Linear Association & 32.182 & & & .000 & & \\
N of Valid Cases & $3.049 \mathrm{~b}$ & 1 & .081 & .095 & .049 & .017 \\
\hline
\end{tabular}

a. 23 cells $(92.0 \%)$ have expected count less than 5 . The minimum expected count is .06 .

b. The standardized statistic is 1.746 .

As shown in Table 10,the value of Fisher's Exact Test is 32.182,Exact Sig.(2-sided) is 0.000 ,lower than 0.05,therefore Hypothesis-4(a)is accepted.

Hypothesis-5(a): Management ability $\left(\mathrm{C}_{5}\right)$ has a significant influence on logistics service satisfaction 
Hypothesis-5(b): Management ability $\left(\mathrm{C}_{5}\right)$ has a lower influence on logistics service satisfaction

Table 11. Logistics Service Satisfaction * C5 Impact Analysis

\begin{tabular}{|c|c|c|c|c|c|c|}
\hline \multicolumn{7}{|c|}{ Chi-Square Tests } \\
\hline & Value & df & $\begin{array}{l}\text { Asymp. Sig. } \\
\text { (2-sided) }\end{array}$ & $\begin{array}{c}\text { Exact Sig. } \\
\text { (2-sided) }\end{array}$ & $\begin{array}{l}\text { Exact Sig. } \\
\text { (1-sided) }\end{array}$ & $\begin{array}{c}\text { Point } \\
\text { Probability }\end{array}$ \\
\hline Pearson Chi-Square & $20.991 \mathrm{a}$ & 16 & .179 & .201 & & \\
\hline Likelihood Ratio & 20.224 & 16 & .210 & .203 & & \\
\hline Fisher's Exact Test & 18.601 & & & .206 & & \\
\hline Linear-by-Linear Association & $3.638 b$ & 1 & .056 & .056 & .032 & .008 \\
\hline $\mathrm{N}$ of Valid Cases & 33 & & & & & \\
\hline
\end{tabular}

a. 25 cells $(100.0 \%)$ have expected count less than 5 . The minimum expected count is .06.

b. The standardized statistic is 1.907 .

As shown in Table 11, the value of Fisher's Exact Test is 18.601,Exact Sig.(2-sided) is 0.206,greater than 0.05,therefore Hypothesis-5(a)is rejected with significant level of 5\%.

Hypothesis-6(a): Service $\left(\mathrm{C}_{6}\right)$ has a significant influence on logistics service satisfaction

Hypothesis-6(b): Service $\left(\mathrm{C}_{6}\right)$ has a lower influence on logistics service satisfaction

Table 12. Logistics Service Satisfaction * C6 Impact Analysis

Chi-Square Tests

\begin{tabular}{|l|r|r|r|r|r|r|}
\hline & \multicolumn{1}{|c|}{ Value } & \multicolumn{1}{c|}{$\mathrm{df}$} & \multicolumn{1}{c|}{$\begin{array}{c}\text { Asymp. Sig. } \\
(2 \text {-sided })\end{array}$} & $\begin{array}{c}\text { Exact Sig. } \\
\text { (2-sided })\end{array}$ & $\begin{array}{c}\text { Exact Sig. } \\
(1 \text {-sided })\end{array}$ & $\begin{array}{c}\text { Point } \\
\text { Probability }\end{array}$ \\
\hline Pearson Chi-Square & $74.888 \mathrm{a}$ & 16 & .000 & .000 & & \\
Likelihood Ratio & 49.919 & 16 & .000 & .000 & & \\
Fisher's Exact Test & 39.233 & & & .000 & & \\
Linear-by-Linear Association & $15.937 \mathrm{~b}$ & 1 & .000 & .000 & .000 & .000 \\
N of Valid Cases & 33 & & & & & \\
\hline
\end{tabular}

a. 25 cells (100.0\%) have expected count less than 5. The minimum expected count is .03.

b. The standardized statistic is 3.992 .

As shown in Table 12, the value of Fisher's Exact Test is 39.233,Exact Sig.(2-sided) is 0.000 ,loeer than 0.05, therefore Hypothesis-6(a)is accepted with significant level of 5\%.

Hypothesis-7(a): Management environment $\left(\mathrm{C}_{7}\right)$ has a significant influence on logistics service satisfaction

Hypothesis-7(b): Management environment $\left(\mathrm{C}_{7}\right)$ has a lower influence on logistics service satisfaction 
Table 13. Logistics Service Satisfaction * C7 Impact Analysis

\begin{tabular}{|l|r|r|r|r|r|r|}
\hline & \multicolumn{1}{|c|}{ Chilue } & \multicolumn{1}{c|}{ df } & $\begin{array}{c}\text { Asymp. Sig. } \\
\text { (2-sided) }\end{array}$ & $\begin{array}{c}\text { Exact Sig. } \\
\text { (2-sided) }\end{array}$ & $\begin{array}{c}\text { Exact Sig. } \\
\text { (1-sided) }\end{array}$ & $\begin{array}{c}\text { Point } \\
\text { Probability }\end{array}$ \\
\hline Pearson Chi-Square & $13.595 \mathrm{a}$ & 12 & .327 & .354 & & \\
Likelihood Ratio & 14.575 & 12 & .266 & .340 & & \\
Fisher's Exact Test & 12.406 & & & .392 & & \\
Linear-by-Linear Association & $.126 \mathrm{~b}$ & 1 & .722 & .750 & .388 & .048 \\
N of Valid Cases & 33 & & & & & \\
\hline
\end{tabular}

a. 18 cells $(90.0 \%)$ have expected count less than 5 . The minimum expected count is .09 .

b. The standardized statistic is -.355 .

As shown in Table 13, the value of Fisher's Exact Test is 12.406, Exact Sig. (2-sided) is 0.392 ,greater than 0.05 ,therefore Hypothesis-7(a)is rejected with significant level of $5 \%$.

Hypothesis-8(a): Quality assurance $\left(\mathrm{C}_{8}\right)$ has a significant influence on logistics service satisfaction

Hypothesis- $8(b)$ : Quality assurance $\left(\mathrm{C}_{8}\right)$ has a lower influence on logistics service satisfaction

Table 14. Logistics Service Satisfaction * C8 Impact Analysis

\begin{tabular}{|c|c|c|c|c|c|c|}
\hline \multicolumn{7}{|c|}{ Chi-Square Tests } \\
\hline & Value & df & $\begin{array}{l}\text { Asymp. Sig. } \\
\text { (2-sided) }\end{array}$ & $\begin{array}{c}\text { Exact Sig. } \\
\text { (2-sided) }\end{array}$ & $\begin{array}{c}\text { Exact Sig. } \\
\text { (1-sided) }\end{array}$ & $\begin{array}{c}\text { Point } \\
\text { Probability }\end{array}$ \\
\hline Pearson Chi-Square & $80.271 \mathrm{a}$ & 16 & .000 & .000 & & \\
\hline Likelihood Ratio & 48.626 & 16 & .000 & .000 & & \\
\hline Fisher's Exact Test & 41.905 & & & .000 & & \\
\hline Linear-by-Linear Association & $20.198 b$ & 1 & .000 & .000 & .000 & .000 \\
\hline $\mathrm{N}$ of Valid Cases & 33 & & & & & \\
\hline
\end{tabular}

a. 23 cells $(92.0 \%)$ have expected count less than 5 . The minimum expected count is .03.

b. The standardized statistic is 4.494 .

As shown in Table 14,the value of Fisher's Exact Test is 41.905,Exact Sig.(2-sided) is 0.000 ,lower than 0.05 ,therefore Hypothesis-8(a)is accepted with significant level of 5\%.

Hypothesis-9(a): Technology $\left(\mathrm{C}_{9}\right)$ has a significant influence on logistics service satisfaction

Hypothesis-9(b): Technology $\left(\mathrm{C}_{9}\right)$ has a lower influence on logistics service satisfaction 
Table 15. Logisitcs Service Satisfaction * C9 Impact Analysis

\begin{tabular}{|c|c|c|c|c|c|c|}
\hline \multicolumn{7}{|c|}{ Chi-Square Tests } \\
\hline & Value & df & $\begin{array}{l}\text { Asymp. Sig. } \\
\text { (2-sided) }\end{array}$ & $\begin{array}{l}\text { Exact Sig. } \\
\text { (2-sided) }\end{array}$ & $\begin{array}{c}\text { Exact Sig. } \\
(1 \text {-sided })\end{array}$ & $\begin{array}{c}\text { Point } \\
\text { Probability }\end{array}$ \\
\hline Pearson Chi-Square & $15.921 \mathrm{a}$ & 16 & .458 & .480 & & \\
\hline Likelihood Ratio & 16.610 & 16 & .411 & .544 & & \\
\hline Fisher's Exact Test & 14.512 & & & .649 & & \\
\hline Linear-by-Linear Association & $.522 b$ & 1 & .470 & .492 & .264 & .048 \\
\hline $\mathrm{N}$ of Valid Cases & 33 & & & & & \\
\hline
\end{tabular}

a. 25 cells (100.0\%) have expected count less than 5 . The minimum expected count is .06.

b. The standardized statistic is .722 .

As shown in Table 15, the value of Fisher's Exact Test is 14.512,Exact Sig.(2-sided) is 0.649 , greater than 0.05 , therefore Hypothesis-9(a) is rejected with significant level of 5\%.

Hypothesis-10(a): Risk $\left(\mathrm{C}_{10}\right)$ has a significant influence on logistics service satisfaction

Hypothesis-10(b): Risk $\left(\mathrm{C}_{10}\right)$ has a lower influence on logistics service satisfaction

Table 16. Logistics Service Satisfaction * C10 Impact Analysis

Chi-Square Tests

\begin{tabular}{|l|r|r|r|r|r|r|}
\hline & \multicolumn{1}{|c|}{ Value } & df & $\begin{array}{c}\text { Asymp. Sig. } \\
\text { (2-sided) }\end{array}$ & $\begin{array}{c}\text { Exact Sig. } \\
\text { (2-sided })\end{array}$ & $\begin{array}{c}\text { Exact Sig. } \\
\text { (1-sided })\end{array}$ & $\begin{array}{c}\text { Point } \\
\text { Probability }\end{array}$ \\
\hline Pearson Chi-Square & $8.407 \mathrm{a}$ & 8 & .395 & .416 & & \\
Likelihood Ratio & 9.535 & 8 & .299 & .423 & & \\
Fisher's Exact Test & 7.867 & & & .428 & & \\
Linear-by-Linear Association & $.112 \mathrm{~b}$ & 1 & .738 & .792 & .396 & .050 \\
N of Valid Cases & 33 & & & & & \\
\hline
\end{tabular}

a. 15 cells (100.0\%) have expected count less than 5. The minimum expected count is . 30 .

b. The standardized statistic is .335 .

As shown in Table 16, the value of Fisher's Exact Test is 7.867, Exact Sig.(2-sided) is 0.428 ,greater than 0.05 , therefore Hypothesis-10(a)is rejected with significant level of $5 \%$.

Hypothesis-11(a): Logistics time $\left(\mathrm{C}_{11}\right)$ has a significant influence on logistics service satisfaction

Hypothesis-11(b): Logistics time $\left(\mathrm{C}_{11}\right)$ has a lower influence on logistics service satisfaction 


\section{Table 17. Logistics Service Satisfaction * C11 Impact Analysis}

\begin{tabular}{|c|c|c|c|c|c|c|}
\hline \multicolumn{7}{|c|}{ Chi-Square Tests } \\
\hline & Value & df & $\begin{array}{l}\text { Asymp. Sig. } \\
\text { (2-sided) }\end{array}$ & $\begin{array}{l}\text { Exact Sig. } \\
\text { (2-sided) }\end{array}$ & $\begin{array}{c}\text { Exact Sig. } \\
\text { (1-sided) }\end{array}$ & $\begin{array}{c}\text { Point } \\
\text { Probability }\end{array}$ \\
\hline Pearson Chi-Square & $41.742 \mathrm{a}$ & 16 & .000 & .000 & & \\
\hline Likelihood Ratio & 37.613 & 16 & .002 & .001 & & \\
\hline Fisher's Exact Test & 28.692 & & & .001 & & \\
\hline Linear-by-Linear Association & $8.364 b$ & 1 & .004 & .003 & .002 & .001 \\
\hline $\mathrm{N}$ of Valid Cases & 33 & & & & & \\
\hline
\end{tabular}

a. 25 cells (100.0\%) have expected count less than 5. The minimum expected count is .12.

b. The standardized statistic is 2.892 .

As shown in Table 17, the value of Fisher's Exact Test is 28.692,Exact Sig.(2-sided) is 0.001 ,lower than 0.05 ,therefore hypothesis-11(a)is accepted.

Hypothesis-12(a): Extendibility $\left(\mathrm{C}_{12}\right)$ has a significant influence on logistics service satisfaction

Hypothesis-12(b): Extendibility $\left(\mathrm{C}_{12}\right)$ has a lower influence on logistics service satisfaction

\section{Table 18. Logistics Service Satisfaction * C12 Impact Analysis}

\begin{tabular}{|c|c|c|c|c|c|c|}
\hline \multicolumn{7}{|c|}{ Chi-Square Tests } \\
\hline & Value & df & $\begin{array}{l}\text { Asymp. Sig. } \\
\text { (2-sided) }\end{array}$ & $\begin{array}{l}\text { Exact Sig. } \\
\text { (2-sided) }\end{array}$ & $\begin{array}{c}\text { Exact Sig. } \\
\text { (1-sided) }\end{array}$ & $\begin{array}{c}\text { Point } \\
\text { Probability }\end{array}$ \\
\hline Pearson Chi-Square & $15.459 \mathrm{a}$ & 16 & .491 & .451 & & \\
\hline Likelihood Ratio & 16.313 & 16 & .431 & .439 & & \\
\hline Fisher's Exact Test & 17.046 & & & .483 & & \\
\hline Linear-by-Linear Association & $1.740 \mathrm{~b}$ & 1 & .187 & .201 & .109 & .029 \\
\hline $\mathrm{N}$ of Valid Cases & 33 & & & & & \\
\hline
\end{tabular}

a. 25 cells (100.0\%) have expected count less than 5. The minimum expected count is .03.

b. The standardized statistic is 1.319 .

As shown in Table 18, the value of Fisher's Exact Test is 17.046,Exact Sig.(2-sided) is 0.483 ,greater than 0.05 ,therefore hypothesis-12(a)is rejected.

Hypothesis-13(a): Validity of the structure $\left(\mathrm{C}_{13}\right)$ has a significant influence on logistics service satisfaction

Hypothesis-13(b): Validity of the structure $\left(\mathrm{C}_{13}\right)$ has a lower influence on logistics service satisfaction 


\section{Table 19. Logistics Service Satisfaction * C13 Impact Analysis}

\begin{tabular}{|l|r|r|r|r|r|r|}
\hline & \multicolumn{1}{|c|}{ Chi-Square Tests } \\
& \multicolumn{1}{|c|}{ Value } & df & $\begin{array}{c}\text { Asymp. Sig. } \\
\text { (2-sided) }\end{array}$ & $\begin{array}{c}\text { Exact Sig. } \\
\text { (2-sided) }\end{array}$ & $\begin{array}{c}\text { Exact Sig. } \\
\text { (1-sided) }\end{array}$ & $\begin{array}{c}\text { Point } \\
\text { Probability }\end{array}$ \\
\hline Pearson Chi-Square & $8.788 \mathrm{a}$ & 12 & .721 & .676 & & \\
Likelihood Ratio & 9.932 & 12 & .622 & .667 & .707 & .224 \\
Fisher's Exact Test & 11.548 & & 1 & .185 & .116 & \\
Linear-by-Linear Association & $1.756 \mathrm{~b}$ & 1 & & & \\
N of Valid Cases & 33 & & & & & \\
\hline
\end{tabular}

a. 18 cells $(90.0 \%)$ have expected count less than 5 . The minimum expected count is .03 .

b. The standardized statistic is -1.325 .

As shown in Table 19, the value of Fisher's Exact Test is 11.548, Exact Sig. (2-sided) is 0.707 ,greater than 0.05 ,therefore hypothesis-13(a)is rejected.

Hypothesis-14(a): Market effect $\left(\mathrm{C}_{14}\right)$ has a significant influence on logistics service satisfaction

Hypothesis-14(b): Market effect $\left(\mathrm{C}_{14}\right)$ has a lower influence on logistics service satisfaction

\section{Table 20. Logistics Service Satisfaction * C14 Impact Analysis}

\begin{tabular}{|c|c|c|c|c|c|c|}
\hline \multicolumn{7}{|c|}{ Chi-Square Tests } \\
\hline & Value & $\mathrm{df}$ & $\begin{array}{c}\text { Asymp. Sig. } \\
\text { (2-sided) }\end{array}$ & $\begin{array}{l}\text { Exact Sig. } \\
\text { (2-sided) }\end{array}$ & $\begin{array}{c}\text { Exact Sig. } \\
\text { (1-sided) }\end{array}$ & $\begin{array}{c}\text { Point } \\
\text { Probability }\end{array}$ \\
\hline Pearson Chi-Square & $33.294 \mathrm{a}$ & 16 & .007 & .008 & & \\
\hline Likelihood Ratio & 29.229 & 16 & .022 & .014 & & \\
\hline Fisher's Exact Test & 25.135 & & & .007 & & \\
\hline Linear-by-Linear Association & $7.950 \mathrm{~b}$ & 1 & .005 & .004 & .002 & .001 \\
\hline $\mathrm{N}$ of Valid Cases & 33 & & & & & \\
\hline
\end{tabular}

a. 25 cells (100.0\%) have expected count less than 5. The minimum expected count is .06.

b. The standardized statistic is 2.820 .

As shown in Table 20, the value of Fisher's Exact Test is 25.135,Exact Sig.(2-sided) is 0.007 ,lower than 0.05 ,therefore hypothesis-14(a)is accepted.

Hypothesis-15(a): Economic benefit $\left(\mathrm{C}_{15}\right)$ has a significant influence on logistics service satisfaction

Hypothesis-15(b): Economic benefit $\left(\mathrm{C}_{15}\right)$ has a lower influence on logistics service satisfaction 


\section{Table 21. Logistics Service Satisfaction * C15 Impact Analysis}

\begin{tabular}{|c|c|c|c|c|c|c|}
\hline \multicolumn{7}{|c|}{ Chi-Square Tests } \\
\hline & Value & df & $\begin{array}{c}\text { Asymp. Sig. } \\
\text { (2-sided) }\end{array}$ & $\begin{array}{l}\text { Exact Sig. } \\
\text { (2-sided) }\end{array}$ & $\begin{array}{c}\text { Exact Sig. } \\
\text { (1-sided) }\end{array}$ & $\begin{array}{c}\text { Point } \\
\text { Probability }\end{array}$ \\
\hline Pearson Chi-Square & $31.448 \mathrm{a}$ & 16 & .012 & .016 & & \\
\hline Likelihood Ratio & 25.463 & 16 & .062 & .049 & & \\
\hline Fisher's Exact Test & 20.662 & & & .068 & & \\
\hline Linear-by-Linear Association & $6.764 b$ & 1 & .009 & .008 & .004 & .002 \\
\hline $\mathrm{N}$ of Valid Cases & 33 & & & & & \\
\hline
\end{tabular}

a. 23 cells $(92.0 \%)$ have expected count less than 5 . The minimum expected count is .06 .

b. The standardized statistic is 2.601 .

As shown in Table 21, the value of Fisher's Exact Test is 20.662, Exact Sig.(2-sided) is 0.068 ,greater than 0.05 ,therefore hypothesis-15(a) is rejected.

\section{Conclusions}

This paper is an attempt to identify the key factors affecting the logistics service quality in China. The primary data for this research are collected through a questionnaire, and Fisher's exact test is applied to identify the criteria of logistics service quality impact analysis. The results could be the guideline for the e-commerce companies in terms of improving their service.

According to the results of the analysis, the main factors affecting logistics service satisfaction are shown in Table 22:

Table 22. The Analysis Result of the Main Factors of the Logistics Service Satisfaction

\begin{tabular}{|l|l|}
\hline Main factor & Exact Sig. (2-sided) \\
\hline$C_{1}$ Cost & 0.002 \\
$C_{2}$ Delivery & 0.000 \\
$C_{4}$ Input-output efficiency & 0.000 \\
$C_{6}$ Service & 0.000 \\
$C_{8}$ Quality assurance & 0.000 \\
$C_{11}$ Logistics time & 0.001 \\
$C_{14}$ Market effect & 0.007 \\
\hline
\end{tabular}

Based on the results of this research, our recommendations for improving the logistics service of the e-commerce companies are: (1) improving the input-output efficiency and market effect; (2) shortening the quality assurance and logistics time; and (3) enriching service.

\section{References}

[1] Q. Lu, F. Meng and M. Goh, "Choice of Supply Chain Governance: Self-managing or Outsourcing?", Production Economics, http://dx.doi.org/10.1016/j.ijpe, vol. 3, no. 22, (2014).

[2] M. Howard and C. Worboys, "Self-service - a contradiction in terms or customer-led choice?", Journal Consume Behavior, vol. 2, no. 4, (2003), pp. 382-392.

[3 V. Carbone and M. Stone, "Growth and relational strategies used by the European logistics service providers: rationale and outcomes", Transportation Research Part E, vol.41, (2005), pp.495-510. 
[4] S. Hertz and M. Alfredsson, "Strategic development of the third party logistics providers", Industrial Marketing Management, vol. 32, (2003), pp. 139-179.

[5] K. H. Lai, "Service capability and performance of logistics service providers", Transportation Research Part E, vol. 40, (2004), pp. 385-399.

[6] S. Yahya and B. Kingsman, "Vendor rating for an entrepreneur development programme: a case study using the analytic hierarchy process method", Journal of Operation Research Society, vol. 50, (1999), pp. 916-930.

[7] Y. Guo and Y. Li, "Analysis of strategic partnership friendship between manufacturer and supplier", Journal of Harbin University of Science and Technology, (1999), pp. 72-75.

[8] H. Jiang and W. Han, "Selection standards and methods on supplier", Science-Technology and Management, vol. 3, (2001), pp. 69-70.

[9] S. Ma and X. Wang, "A study on the method of determining supplier evaluation index-weight", Industrial Engineering and Management, (2002), pp. 5-8.

[10] W. Zhong and Q. Hou, "A study on evaluation indicator system and evaluation model of suppliers", The Journal of Quantitative \& Technical Economics, (2003), pp. 93-97.

[11] J. Zhou and L. Wang, "Analysis of influence factors of customer satisfaction on the third party logistics enterprise", Logistics Technology, (2005), pp. 30-33.

[12] Y. Sun, "Constructing of the evaluation index system of third-party logistics operation efficiency", Special Zone Economy, (2006), pp. 58-60.

[13] H. Hsiao, et al., "A classification of logistic out sourcing levels and their impact on service performance: Evidence from the food processing industry", Int. J. Production Economics, vol. 124, (2010), pp. 75-86.

[14] J. Peng, "Selection of Logistics Outsourcing Service Suppliers Based on AHP”, Energy Procedia, vol. 17 , (2012), pp. 595-601.

[15] C. I. Ho and Y. L. Lee, "The development of an e-travel service quality scale", Tourism Management, vol. 26, (2007), pp. 1434-1449.

[16] C. Liao and H. Kao, "An evaluation approach to logistics service using fuzzy theory, quality function development and goal programming", Computer \& Industrial Engineering, vol. 68, (2014), pp. 54-64.

[17] R. A. Fisher, "On the interpretation of $\chi 2$ from contingency tables, and the calculation of P", Journal of the Royal Statistical Society, vol. 85, no. 1, (1922), pp. 87-94.

\section{Author}

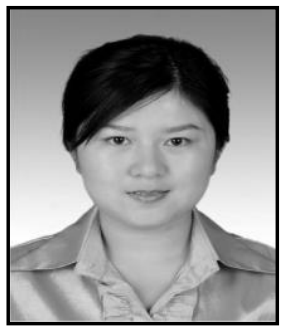

Ning Lei. Female, born on April 3, 1982. Now, she is a lecturer in Xi'an International University. She has master's degree in engineering. Her research directions are e-commerce logistics management and transportation management. 